Summer 2004

\title{
Re-Greening the South and Southernizing the Rest
}

Mart A. Stewart

Western Washington University, mart.stewart@wwu.edu

Follow this and additional works at: https://cedar.wwu.edu/history_facpubs

Part of the Environmental Studies Commons, and the History Commons

\section{Recommended Citation}

Stewart, Mart A., "Re-Greening the South and Southernizing the Rest" (2004). History Faculty and Staff Publications. 21. https://cedar.wwu.edu/history_facpubs/21

This Article is brought to you for free and open access by the History at Western CEDAR. It has been accepted for inclusion in History Faculty and Staff Publications by an authorized administrator of Western CEDAR. For more information, please contact westerncedar@wwu.edu. 


\title{
Re-Greening the South and Southernizing the Rest
}

\author{
MART A. STEWART
}

In 1759, not long after he was appointed the first governor of the relatively new colony of Georgia, Henry Ellis, who went about the streets of the capital under an umbrella with a thermometer suspended from it, wrote to the folks back home in London that the inhabitants of Savannah "breathe a hotter air than any other people on the face of the earth." His calculation of temperature was a dialogue between instrument and body, which factored in prominently his own discomfort and engaged in a hyperbole that participated in a larger projection about the climate of Savannah's latitude. Ellis returned to England soon after, but for English settlers in Virginia, the Carolinas, Georgia, and later, Florida, the South was, for part of the year anyway, a distinctively near-tropical land. Historians have long acknowledged that the southern environment was different-that Native Americans lived differently on the land in the southern regions than elsewhere in North America, and that the process of adaptation, or "seasoning," as it was called by early setters-was more

Mart A. Stewart is Professor of History and Affiliate Professor at Huxley College of the Environment at Western Washington University and author of "What Nature Suffers to Groe": Life, Labor, and Landscape on the Georgia Coast, 16801920 (1996; pb 2003). He is currently working on a cultural history of climate in America.

1. Henry Ellis, "An Account of the Heat of the Weather in Georgia," London Magazine, Mar. 1759, 371. Conevery Bolton Valenčius, The Health of the Country: How American Settlers Understood Themselves and Their Land (New York, 2002), convincingly demonstrates that physical environments were more significantly measured by intimate exchanges between bodies and airs, waters, and soils than by observations with instruments by early Americans. Ellis took measurements, but was ultimately driven to return to England by what he breathed. 
complicated for Europeans in southeastern North America than in New England. Part of this region, along the Atlantic and Gulf coasts especially, in environmental terms resembled the Caribbean or West Africa more than Europe. For many European organisms, including human beings (whether with thermometer or not), the South was not a neoEurope. Even those that thrived in southern environments did so in a different way than in other parts of North America. ${ }^{2}$

It was not quite a neo-Africa, either. Organisms from Africa and Europe met in the environmental circumstances of the South to create much of what was distinctive about the South: open-range cattle raising, a fear of fevers, wet-culture rice production, and the other long-season crops such as sugar, tobacco, and "king cotton." The literature on southern agriculture and labor systems, on diseases and on southern medicine, and on cattle herding practices in the South, is vast, but much of it still does not take into account the intimate-breathing-relationship human and other organisms had with the climate, soils, and waters that they sought to inhabit. Nor does existing scholarship accomplish a groundlevel analysis of the environments that produced the South. Much of the literature about agriculture, disease, and other subjects related to the South in fact has extracted its subject from that which is most crucial to understanding it: the contextual relationship of organisms to the physical environments. Recovering how humans understood these relationships is also important. As Robert Weir advised twenty years ago in his fine history of colonial South Carolina, early settlers paid remarkable attention "to details which only a few individuals would now notice, such as the direction of the prevailing winds, the height of the tides, and the consistency of the soil. These observations suggest something which should be obvious but is frequently overlooked in a period of technological and scientific hubris. During the seventeenth and eighteenth centu-

2. On "Neo-Europes," see Alfred W. Crosby, Ecological Imperialism and the Biological Expansion of Europe, 900-1900 (Cambridge, UK, 1986), passim. On the relationship between the physical environments of the southern low country and West Indies (such as Barbados) and West Africa, see Peter Wood, Black Majority: Negroes in Colonial South Carolina from 1670 through the Stono Rebellion (New York, 1974), 13-94; Daniel Littlefield, Rice and Slaves: Ethnicity and the Slave Trade in Colonial South Carolina (Baton Rouge, 1981), 84-92; Mart A. Stewart, "What Nature Suffers to Groe": Life, Labor, and Landscape on the Georgia Coast, 1680-1920 (Athens, GA, 1996), 138-50; and Judith Carney, Black Rice: The African Origins of Rice Cultivation in the Americas (Cambridge, MA, 2001). 
ries, everyone, even the most wealthy and sophisticated, lived relatively close to nature." Simply, he noted, "physical geography made a difference. ${ }^{\prime 3}$ How the physical environment, and the organisms that were a part of it, were perceived, experienced, and manipulated was crucial to how the South came to define itself.

Take the cattle raising industry that was so important to southern economies in the colonial period and well into the early republic. Historians have examined in almost excruciating detail the herding and branding practices of southern open-range cattle raising, the possible cultural antecedents (sources of "pre-adaptation") of herding practices, the evolution of "fence" and then "stock" laws for regulating the relationship between crops and stock, and (to a lesser extent) the economics of cattle raising. A few accounts of cattle-raising have paid some attention to the ecological relationship between cattle, human settlements, and local environments; but most analyses of cattle raising focus on larger patterns and cultural practices. They have not looked at what colonial herders themselves had to take most seriously: the relationship between seasonal availability of feed and water on a scale large enough to support the large herds of cattle that were fundamental to the success of open-range cattle raising. Herders also had to consider the behavior of cattle themselves, who went feral when given the opportunity at an early age. The practices and conceptions of cattle that colonists brought with them shaped their understanding of their animals' behavior; but the impact of local ecosystems-what cattle could eat and where-was much more crucial to the development of the industry in each locale. And as controversial as the point may appear to be to historians, who after all are specialists in the study of humans, cattle too had agency. ${ }^{4}$

3. Robert M. Weir, Colonial South Carolina: A History (Millwood, NY, 1983), 35.

4. Several scholars, as part of a lively sometimes tumultuous debate that has important implications for environmental history, have argued that cattle-herding in South Carolina was merely the first application in North America of "preadapted" cultural baggage carried by certain ethnic groups, mainly West African and Celtic: Wood, Black Majority, 28-33; John Solomon Otto, "The Origins of Cattle-Ranching in Colonial South Carolina, 1670-1715," South Carolina Historical Magazine, 87 (1986): 117- $\rightarrow \rightarrow$ Grady McWhiney and Forrest McDonald, "Celtic Origins of Southern Herding Practices," Fournal of Southern History, 51 (1985): 165-82. Earlier studies that suggest Spanish (by way of the West Indies and Spanish Florida) origins for herds and herding practices include Lewis Cecil 
How cattle herding was absorbed into deeply rooted ways of living on the land proved almost as important as how colonists modified, borrowed, or re-invented "pre-adapted" herding practices to meet local conditions. At first cattle were interlopers in Creek country, for example, but by the end of the eighteenth century most Creeks owned cattle and hogs. Cattle herds became an important indicator of wealth for the métis elite among the Creeks, and many Creeks possessed large enough herds that they qualified as ranchers more than farmers. Women also traded in cattle, in roles that complemented their traditional activities as traders. Creek herds were free-ranging, but Creek herders also required an adequate amount of browse within the larger areas within which their herds grazed. The relatively mild winters of the Southeast made it possible to keep cattle out on the open range year-round in the first place, but winter

Gray, History of Agriculture in the Southern United States (2 vols., Washington, DC, 1933), 1:140, 151, see also 78-79; and Frank Lawrence Owsley, Plain Folk of the Old South (Baton Rouge, 1949), 26-29. Terry Jordan and Matti Kaups claim that the influence of Savo-Karelian culture provided crucial components of "American backwoods" culture in general: The American Backwoods Frontier: An Ethnic and Ecological Interpretation (Baltimore, 1989). Several other studies examine southern cattle-raising in general in Virginia, South Carolina, Georgia, or Alabama, but the most comprehensive examination of cattle raising practices in the early South, which also argues that characteristic herding practices traveled a trail from South Carolina to Texas is Terry G. Jordan, North American CattleRanching Frontiers: Origins, Diffusion and Differentiation (Albuquerque, 1993). Interpretations of the struggle over the stock laws differ greatly. See, for example, Steven Hahn, "Hunting, Fishing, and Foraging: Common Rights and Class Relations in the Postbellum South," Radical History Review, 26 (1982): 37-64; and Shawn E. Kantor, Politics and Property Rights: The Closing of the Open Range in the Postbellum South (Chicago, 1998). Virginia DeJohn Anderson's "Animals into the Wilderness" steps around the debate about "pre-adaptation" by simply ignoring the literature and also by focusing on a colony more or less off the trail: Virginia. She adds to our understanding of cattle behavior in the southern colonies-how cattle had agency-as well as the perceptions and practices of the colonists who sought to manage and use them: Anderson, "Animals into the Wilderness: The Development of Livestock Husbandry in the SeventeenthCentury Chesapeake," William and Mary Quarterly, 59 (2002): 377-408. An earlier study that looks at a colony that was on the trail, Georgia, and that examines the behavior of cattle and local ecological conditions as well as the development of institutions and cultural structures for managing cattle raising within the colony, $\rightarrow$ Mart Stewart, "Whether Wast, Deodand or Estray?": Cattle, Culture, and the Environment in Early Georgia, Agricultural History, 65 (Summer, 1991): 1-28. 
feed was always a problem. Southern forests and savannah were rank with vegetation, and quite a bit of it was green in the winter, but little of this vegetation provided enough digestible protein to keep cattle alive in the winter. River reed cane, which remained succulent and green throughout the winter months and which provided both cover and feed for cattle and hogs, was essential to the Creek range, as it was to southern cattle herding everywhere. The fate of cattle herding in Creek country depended on the presence of large brakes of river cane in which cattle could keep themselves alive during the winter. Cane is a resilient plant and even thrives when brakes are disrupted or burned. But cattle tend to "patch graze"-they congregate and feed as a group. In canebrakes, this compacted the soil, which in turn inhibited new growth in the brakes, at the same time that the hungry stock stripped the cane of leaves. When hogs fed on the cane as well, they rooted out new cane shoots, which killed the plants. By the beginning of the nineteenth century, overgrazing had begun to destroy the canebrakes in Creek country. And though other factors affected the valuable cattle industry of the Creeks, overgrazing and the need to disperse to exploit better the range resources that were available in Creek country may have been important in changes in settlement patterns among the Creeks in the early nineteenth century -as they separated from central towns and scattered in smaller settlements and finally farmsteads throughout the countryside. Whether removal to farmsteads compromised matrilines, multi-family households, and communal farming practices and encouraged the development of patriarchal nuclear families requires more investigation. But in part because of the changing relationship of cattle and cane in Creek country, Creek farming and ranching had by the early nineteenth century begun to look much like white frontier farming. ${ }^{5}$

5. Acknowledging that local conditions and adaptations were as least as important as "pre-adaptation" and "cultural hearths" to the history of southern cattle raising does not make an explanation that is "self-contradictory." Terry Jordan's North American Cattle-Ranching Frontiers (177) is unnecessarily combative on this point, as it appears in "Whether Wast, Deodand, or Estray?"; his study on the whole in any case attends to both "adaptation" and "pre-adaptation." For those who were actually doing the herding, what they found on the ground for their cattle and by way of their cattle was of more immediate importance than where their herding practices came from, and much more attention needs to be paid to discrete local ecological and cultural factors in the relationship between cattle and humans in the South-this is my point in "Whether Wast," and here. 
Uncultivated parts of the South continued to provide both sustenance and social landscapes for antebellum southerners. Southerners of all kinds continued to raise cattle and hogs in the uncultivated spaces of the region until late in the nineteenth century when stock laws forced them to fence livestock in rather than out. In some locales open range herding continued to be an important economic activity until well into the twentieth century. Hunting and fishing supplemented livelihoods garnered from cultivation and raising livestock, and the open lands of the South remained important for these. Uncultivated "nature" also provided both highway and sanctuary to African Americans who were slaves on the farms and plantations of the South. Slaves who sought either to escapeeven if just for a while - the harsh constraints of plantation life, or who traveled to other plantations to visit family, traveled or hid out off the roads. Grand marronage, as the French called it in Louisiana, was not common in the South, but also it was not unknown. More common was the petit marronage engaged in by slaves who sought temporary respite from a particularly repressive master or overseer or who wanted to visit with family on other plantations. Such periods of truancy to visit kinfolk dramatically improved the quality of family relations. The physical environment off the plantation, then, was an intricate part of the elaborate geography of kinship in the antebellum South. ${ }^{6}$

Uncultivated land-about 80 percent of the land on the eve of the Civil War-was never truly vacant, never really "out there" for southerners, in a way that fostered ideas about "wildness." The open places of the South were not as wild as open places elsewhere in the United States. No Puritan communities demonized the "wild" in the first place, and no Henry David Thoreau tried to make it sublime. In any case Thoreau's ideas would not likely have taken root in a region where environmental

For Creek herding practices, see Robbie Ethridge, Creek Country: The Creek Indians and Their World (Chapel Hill, 2003), 160-74.

6. Stewart, "Whether Wast, Deodand or Stray," chaps. 3 and 4, passim; Gwendolyn Midlo Hall, Africans in Colonial Louisiana: The Development of Afro-Creole Culture in the Eighteenth Century (Baton Rouge, 1992), 201-36; Gilbert C. Din, Spaniards, Planters, and Slaves: The Spanish Regulation of Slavery in Louisiana, 1763-1803 (College Station, TX, 1999), 19-34. Philip Morgan explains how recurrent patterns of running away by eighteenth-century slaves were connected to patterns of visiting, and even does the math: Slave Counterpoint: Black Culture in the Eighteenth-Century Chesapeake and Lowcountry (Chapel Hill, 1998), 524-30. 
sensibilities have always been deeply agrarian-or at least, pastoral. "Wilderness," even where it was identified, was usually teeming with cattle and hogs, or hunters and fishermen. Or it was a place to run to, in efforts to escape extreme hardship or consolidate family connections. For African Americans who were slaves, the wilderness made quite a different impression than it made on Thoreau. Slaves plunged into the swamps not to find the world but to lose it. In the wilderness they found each other rather than themselves. Conservation and environmental thought consequently tapped different sources in the South than in other regions; southerners always assumed that environments conserved would also always be environments inhabited.

Conservation emerged not from an accommodation with wildness or wilderness and an eventual appreciation of it, nor out of fear of dwindling "natural resources," but out of concerns about the declining fertility of southern soils and the competitive advantage of the southern economy in a nation where the South had begun to feel embattled. In other words, in the antebellum South, conservation meant agricultural improvement. Planters especially were concerned about soil exhaustion in the older regions; the better educated in Virginia, South Carolina, and Georgia began to argue for changes in farming methods that would preserve or restore fertility, rather than mine it to death and then escape to fresh lands in the West. Such improvers "assumed that they had to be what one called, 'good stewards,' because the land was vulnerable and human beings had to work carefully within its limitations," explains Joan Cashin. Improving planters developed elaborate methods for manuring, rotating crops, resting arable land, and most famously, excavating and amending soils with marl. Their efforts did not really accomplish reform, and in the end the rhetoric of agricultural reform in the South produced a good deal more air than improvement. But at the heart of the efforts by improving planters to recover the fertility of the older agricultural regions of the South was an ecological sensibility. "Long before the science of ecology," Steven Stoll explains, "they came closer than anyone before them to a full (if sometimes inaccurate) sense of interdependence among organisms and interconnectedness in nature generally."

7. Joan E. Cashin, "Landscape and Memory in Antebellum Virginia," Virginia Magazine of History and Biography, 102 (Oct. 1994): 483. See also Jack Temple Kirby, "Virginia's Environmental History: A Prospectus," Virginia Magazine of 
The history of conservation in the South, or of the agricultural improvement movement in the United States in general, is the history of failure. Farmers and planters who sought to retard the flight to fresh westward lands and to inspire a more intricate and intimate relationship between husbandman and land were not successful, and ecological sensibilities were overcome by economic and demographic forces. But just because this kind of conservation failed does not mean that it was not deeply important to the South-a region that remained profoundly agrarian until at least World War II and that has been, after all, as much conditioned and defined by defeat and failure as by success.

Much of the history of these early conservation efforts in the South remains to be written, and it needs to be more fully connected to efforts to improve the productivity of slaves and make the institution of slavery more palatable to critics in both regions. The agricultural improvement movement in the South cannot be separated from the social context in which it took place, nor extracted from the political economy that shaped it. Paternalists all, improving planters sought to improve slave management techniques. While they advocated a more respectful attitude toward the land that gave them their livelihoods, they also argued for the humanity of slaves and a more humane treatment of the human property that also sustained them, modeling their role after that of the firm but understanding father toward his children.

Indeed, the shifting perceptions of slaves by their owners-who regarded them more as working pets than as humans-should also be studied more closely as part of a larger effort to discern the sources of conservation values in the South. Ideas about conserving nature were intricately connected to ideas about improving the management of slaves. They talked about modes of improvement with the same intensive detachment that they talked about labor in the fields, as if they themselves accomplished it. The enormous labors contributed by their slaves-in the work of marling and manuring as well as in the traditional tasks of southern agriculture-were simply invisible to them. Planters who sought

History and Biography, 99 (1991); Mart A. Stewart, "What Nature Suffers to Groe," chap. 4; Jack Temple Kirby, Poquosin: A Study of Rural Landscape and Society (Chapel Hill, 1995), passim; and especially Steven Stoll, Larding the Lean Earth: Soil and Society in Nineteenth-Century America (New York, 2002), 120-68 (quotation at 167). 
to improve the lots of both land and slaves were green paternalists, not husbandmen. ${ }^{8}$

Some historians have argued that this was the problem with the South: the relative value of labor to land prevented agricultural reform from accomplishing very much. ${ }^{9}$ The development of conservation thought in nineteenth-century America and changing perceptions of African-American slaves were linked, no matter how perversely. Such conservative attitudes, bound up with a set of ideas about race that have been discredited entirely, may seem less interesting to historians who traditionally have favored more liberal shades of green. But that, of course, is judging the past by the standards of the present, and it also does not acknowledge the fact that environmental thought in the South may have important connections with the agrarian tradition.

Black southerners also created a conservation ethos, and this has only begun to be examined. African-American environmental values in the South have their roots in the history of slavery. A close attention to the land, cultivated and uncultivated, was also a form of resistance, and not just by running away. African Americans who knew where to find game or fish, who gathered wild foods to supplement their rations, or who planted patches of rice or corn in the woods, expressed an attention to the land that was discreet and nuanced, even while it derived from their status as slaves. How this ethos was further shaped by the experience of emancipation and the development of postbellum patterns of agriculture and segregation and later by contact with progressive ideas about agricultural improvement needs to be examined more fully, but it is a story that began in the early South.

Soil exhaustion and the political economy of the plantation are more important to an understanding of landscapes in the early South than questions about wilderness and sensibilities forged by an experience (or perception) of uninhabited nature. Southern life was intimately entwined with the environment with or without a thermometer to mediate it; but the peculiar American conceit about a "wilderness" or "pristine nature,"

8. For the history of the changing perceptions of slaves by masters, from a view that saw them as less savage and more "human," but that still likened them to domestic animals and to "pets," see Karl Jacoby, "Slaves by Nature? Domestic Animals and Human Slaves," Slavery and Abolition, 15 (1994): 89-99. For "green paternalism," see Stewart, "What Nature Suffers to Groe," 186-88.

9. See Stoll, Larding the Lean Earth, 158. 
that was unpeopled and even outside of history has never taken a strong hold in the South.

In this way the environmental history of the South looks a lot like the environmental history of just about everywhere else in the world outside of the United States. Recently a prominent American historian claimed that in regard to environmental history, the South was "again the backward region." As the environmental history of the South is exposed and recovered, and historians explain more fully the intimate relationship between agriculture, agrarian and pastoral sensibilities, the history of slavery, and the physical environment of the South, we may discover that the South is instead out in front, waiting for the rest of America to catch up. Environmental historians of other regions in the United States, or indeed environmentalists in general who are seeking a usable past, may once again find a great deal to learn from historians of the South. ${ }^{10}$

10. In a recent essay, Richard Judd argues from another region-New England-and observes that many of the basic questions that have driven discussions in environmental history really come out of the field's origins in the history of the West. See Richard W. Judd, "Writing Environmental History from East to West," in Ben A. Minteer and Robert E. Manning, eds., Reconstructing Conservation: Finding Common Ground (Washington, DC, 2003), 19-31. For the "backward region" characterization, see Otis Graham, "Again the Backward Region: Environmental History In and Of the American South," Southern Cultures, 6 (Summer 2000): 50-72. See also Mart Stewart, "Southern Environmental History," in John Boles, ed., Blackwell Companion to the American South (Malden, MA, 2002), 409-23. 